\title{
CORRESPONDENCIA ERUDITA ENTRE D. AGUSTÍN PABLO DE ORDEÑANA Y EL PADRE FEIJOO*
}

\author{
Cristina González Caizán**
}

En la Biblioteca Nacional de Madrid, sección de Raros y Manuscritos (mss. 1715), hemos encontrado una correspondencia erudita entre D. Agustín Pablo de Ordeñana ${ }^{1}$ y el Padre Feijoo. El carteo entre ambos ilustrados gira en torno a dos asuntos; el primero, trata sobre la prohibición dada por Fernando VI en 1750 de criticar las obras de Feijoo y, el segundo, gira en torno a dos de los despotismos más característicos del siglo XVII el ruso y el francés o, lo que es lo mismo, Luis XIV y Pedro I. La disputa se inicia a raíz de la publicación del tercer tomo de las Cartas Eruditas del monje benedictino, Ordeñana encuentra todas las cartas propias de su autor a excepción de la que establece el paralelo entre el monarca francés y el ruso. Luis XIV no sale muy bien parado en esta comparación y Ordeñana sale en su defensa. Ordeñana y toda la red de clientes y hechuras del Marqués de la Ensenada eran fieles partidarios de la política del Rey Sol y no podían permitir el ataque que de su figura hace Feijoo por lo que Ordeñana, al escribir al erudito asturiano, venía a ser una especie de por-

* Este trabajo se inscribe en el proyecto financiado por la DGYCIT PB 95-0698 "El tiempo de Ensenada" dirigido por J. L. Gómez Urdáñez al que la Universidad de La Rioja ha concedido también una Ayuda a la investigación para el grupo del que forma parte la autora.

** Universidad de La Rioja.

1. Agustín Pablo de Ordeñana fue la principal hechura del Marqués de la Ensenada. Nació en 1711 en Bilbao. Fue secretario y hombre de confianza del marqués en el Almirantazgo con tan sólo 26 años. En 1741 acompañó a Italia al Infante don Felipe como Oficial Mayor de la Secretaria de Estado del Infante que era. En 1743 fue nombrado Secretario de Guerra del Infante y regresó a Madrid ese mismo año al ser nombrado consejero del Consejo de Hacienda. En 1744 se le concedió el hábito de la orden de Calatrava. En 1752 obtuvo una plaza de Consejero de Estado y Guerra y en 1754, año de su destierro a Valladolid, se le encargaron las obras del Real Palacio de Madrid. En 1761, y después de siete años de ostracismo, Carlos III le devolvió la libertad y su plaza de consejero del Consejo de Guerra. Murió en 1765. 
tavoz ensenadista. Las relaciones hispano-francesas no estaban atravesando por sus mejores momentos, las relaciones familiares se habían debilitado mucho después de la muerte de Felipe $V$, por lo que el ataque que hace Feijoo a la figura del rey francés puede ser mal interpretado por otras facciones de poder en la corte de Fernando VI, una corte que ya había apostado por la españolidad como ideología que superase la vieja dependencia de los tiempos de Felipe $\mathrm{V}$ e Isabel de Farnesio.

Estas cartas fueron escritas entre el 30 de junio de 1750 y el 28 de febrero de 1751, por medio de su lectura conoceremos las opiniones que sobre gobierno y política tuvieron tanto el "brazo ilustrado" de Ensenada como el monje benedictino. También conoceremos sus opiniones sobre algunos de los autores más importantes del siglo como Voltaire o Moreri; sobre obras tan importantes en la época como el Diccionario de Moreri, las Causas Célebres de Gayot de Pitaval o la Historia de Carlos XII de Suecia de Voltaire y las opiniones que despertaron en ambos la vida amorosa en la corte de Luis XIV. Las cartas tienen un gran valor en sí mismas de ahí la necesidad de su transcripción. Una de las cartas ha sido ya transcrita por Luis Sánchez Agesta ${ }^{2}$, en esta obra se reproduce la carta donde Ordeñana discute a Feijoo quién puede ser mejor rey para un país; Ordeñana defiende la política de conquistas de Luis XIV, mientras Feijoo alaba la política pacificadora del zar Pedro I.

\section{Transcripción de la correspondencia erudita entre Agustín Pablo de Ordeñana y el Padre Feijoo}

\section{ORDEÑANA-FEIJOO. ARANJUEZ, 30 DE JUNIO DE 1750}

Muy señor mío: Muchos habrá que con motivo de la orden del rey ${ }^{3}$ comunicada al gobernador del Consejo para no permitir la impresión del tercer tomo del Padre Soto y Marne 4 llenen a usted de para bienes y con razón, porque es un honor que le distingue entre los hombres más famosos que ha pro-

2. SÁNCHEZ AGESTA, L., Escritos políticos de Fray Benito Jerónimo Feijoo y Montenegro, Madrid, 1946, pp. 535-542

3. Se refiere al Real Decreto de Fernando VI de 1750, en él el Rey prohibió que se imprimiesen libros que atacasen a Feijoo. La Real Orden dice: "Quiere su Majestad que tenga presente el consejo que, cuando el Padre Maestro Feijoo ha merecido a su Majestad tan noble declaración de lo que le agradan sus escritos, no debe haber quien se atreva a impugnarlos y, mucho menos que, por su consejo, se permita imprimirlos". 23 de junio de 1750 . BN. mss. 10579.

4. Francisco de Soto y Marne. Cronista General de la orden Franciscana y lector de teología en un Convento de Observantes de Ciudad Rodrigo. Literalmente era conocido por una disparatada colección de sermones. En esta carta se refiere al tercer tomo de sus Reflexiones crítico-apologéticas donde Soto y Marne atacaba a Feijoo y le acusaba de copiar a Bacon y Buffier tachándolo incluso de hereje. Fernando VI promulgando su Real Orden frenó este tipo de ataques contra la obra de Feijoo. 
ducido la República Literaria y aún la Iglesia de Dios. En esta parte mi satisfacción no cede a la de todos porque ninguno estima más que yo el elevado mérito de usted; pero por lo mismo debo interesarme en que no padezca la menor nota su opinión y quede su memoria a la posteridad con la gloria bienquista. A trueque de tan buen deseo, espero lleve usted a bien las reflexiones que voy a hacer.

Aunque la expresada prohibición no sea (como no es) efecto de la solicitud de usted habrá no pocos que lo crean y aseguren y cuando no, lo atribuyan a vicio de su amor propio o presunción nacida del concepto de ser infalible su doctrina, se persuadirán a que ha tenido usted el nuevo ataque de Soto y Marne. Ya veo que ésto será no conocer los considerables beneficios de usted sobre tal competidor; pero como no es la razón la que así impresiona en lo más correrá la voz, no sin disgusto de usted, pues se lo produjeron los dos primeros tomos, hasta el punto de dar al público sus sentimientos.

Dirá usted, y aún dijo, que eran insuficientes los dicterios y calumnias que contenían, yo diría que eran despreciables pero, ¿qué dirán ahora los que sepan que el Padre Soto y Marne ha ofrecido la enmienda en esta parte? ${ }^{5}$, ¿no podían inferir que es otro el motivo de prohibirse la impresión de su tercer tomo?. Todos venerarán la solución del rey pero como en asuntos probables corre en libertad el discurso de cada uno, obedecerán con resignación en la parte de no dar a la estampa las impugnaciones a que están sujetas las obras de usted como todas las de su naturaleza. Usted mismo, en algunos puntos de ellas, habrá hallado con el tiempo y más madura reflexión bastante que enmendar o rectificar y si ha leído las Observaciones ${ }^{b}$ de nuestros marineros Don Jorge Juan y Don Antonio de Ulloa, se habrá convencido de que no son subsistentes las razones con que intenta usted probar que el mundo es de figura ovalada.

Por éstas y otras consideraciones que omito para no hacer más prolija esta carta sería yo del dictamen, salvo el mejor de usted, que agradeciendo usted al rey de lo íntimo de su corazón una honra tan distinguida, le pidiese con eficaz ruego que levantase la prohibición cuando no a favor del Padre Soto y Marne al de los demás que no han incurrido en igual culpa, para que así quede libre el campo a los modestos investigadores de la verdad.

Tengo tal concepto del buen juicio y moderación de usted que casi me atrevo a asegurar que antes que haya leído mi carta lo habrá ya determinado $y$, tal vez, puesto en ejercicio. Yo lo celebraré para que así confunda usted más a sus enemigos y haga eterna su fama con una acción heroica digna de los mayores elogios.

5. Efectivamente la respuesta de Soto y Marne no se hizo esperar y publicó un Memorial que presentó a Fernando VI en el mismo año de 1750. Tras la publicación de este Memorial se produjeron escritos satíricos contra Soto y Marne aunque también hubo voces que salieron en defensa del monje franciscano.

6. Se refiere a la obra de don Jorge Juan y de don Antonio de Ulloa Observaciones astronómicas y físicas hechas por orden de S. M. en los Reinos de Perú. Madrid, 1748. Esta obra la tuvo Ordeñana en su biblioteca. 
Disimule usted mi confianza y la franqueza con que le propongo lo que considero más propio de su gloria, asegurando de que a una y otra me mueven las venas de la devoción y parcialidad que profeso a usted con la mayor propensión a servirle. Dios guarde a usted muchos años como deseo.

\section{ORDEÑANA-FEIJOO. MADRID, 12 DE SEPTIEMBRE DE 1750}

Muy señor mío: Gracias a usted, y se las doy de muy de corazón, por el tercer tomo de sus Cartas Eruditas ${ }^{7}$ que de su orden me entregó el librero Atena. Este favor queda con profunda raíz impreso en mi agradecimiento para estimarle siempre y procurar corresponder a usted con mi obediencia y obsequio en cuanto de su satisfacción.

Luego que recibí el libro empecé a leerlo y habiendo continuado esta gustosa tarea según me lo han permitido las indispensables de mis encargos hallo, y lo expongo sin lisonja, que casi todas las cartas que he visto son muy dignas de usted que es el mayor elogio con que puedo graduar su mérito. He dicho casi todas porque no me atrevo a formar igual juicio del Paralelo de Luis XIV rey de Francia y de Pedro I el Zar de Moscovia. Puede ser provenga ésto de tener preocupada la mente con la idea ventajosa que siempre he tenido del primero considerando que la fama nada le ha dado graciosamente en su aplauso y que el renombre de grande con que le conoce el mundo es la medida justa de sus regias prendas y gloriosas acciones. No pienso hacer aquí su apología; mucho menos vindicar su mérito sea cual fuere de lo que en descrédito de él intenta probar el paralelo. Sólo diré a usted que éste ha ofendido a toda la nación francesa, que llevaba muy mal se afee en él la memoria de un rey que es el objeto de su mayor veneración y aún de la de toda Europa.

No descubren los franceses qué razón de congruencia o utilidad pública haya podido mover a usted a declamar con tanto esfuerzo contra Luis XIV, si no es que traía considerado usted preciso destruir la opinión de este príncipe para fundar sobre su ruina la del Zar Pedro imitando en ésto a muchos de nuestros predicadores que creen no elogian bastante en su panegírico al santo del día, sino bajan el valor de aquéllos o aquél con quien le comparan. Dicen que falta usted a la verdad, no sin cargo de su conciencia, publicándole incontinente de por vida a un don aquella restricción casi, porque hechos los cálculos correspondientes le sacan a lo menos las dos terceras partes de ella exentas de este vicio que no se le conoció hasta su amistad con La Vallière y tuvo fin en su matrimonio con la Maintenon que duró veinticinco años, sin que en todo él extraviase de este objeto su cariño. Ni se puede asegurar que sus primeros amores fueron criminales.

7. Las Cartas Eruditas se publicaron por primera vez entre 1742 -primer tomo-y 1760 -el $\$$ tomo-. El tercer tomo fue publicado el 4 de agosto de 1750 . Ordeñana tuvo en su biblioteca varias de las obras de Feijoo tales como el Teatro Crítico Universal o la Justa Repulsa de inicuas acusaciones. Precisamente en esta última obra Feijoo se defendía de los ataques de Soto y Marne e intentaba demostrar que no copiaba a ningún otro autor y que sus citas eran auténticas. 
Les es sensible hasta la irritación que usted le despoje del mérito de todas las cosas grandes que hicieron glorioso su reinado atribuyéndoselas únicamente à su género y ministros, como si en los aciertos de éstos no influyese la buena dirección del príncipe que es la parte del decreto intensivo, y se debiese contar por nada la discreta elección y útil uso de ellos, excelencia que aún usted considera digna del aplauso del rey en su dedicatoria. Al tiempo que no hallan en el paralelo la mayor indulgencia hacia Luis XIV siendo, dicen, todo él un estudiado empeño de abultar sus defectos y deshacer sus buenas cualidades políticas y morales.

Reparan que con el mismo empeño y pasión intenta usted excusar y hacer menos graves del zar realzando excesivamente su mérito en muchas cosas que, bien examinadas, ni fueron lo que figura usted o no contribuyen al heroísmo en parte alguna. Esta parcialidad la creen recusable e impropia de un paralelo que en fiel balanza y con discreta indiferencia debe pesar las virtudes y vicios de los sujetos que compara sin que el afecto, el odio ni la preocupación le inclinen más a uno que a otro. Dando a cada uno lo que le pertenece de justicia, pues hace las veces de juez y no puede ser bueno el que se apasiona a favor de una de las partes.

Dicen también que usted sube con tanto exceso al uno y baja al otro que no deja entre los dos proporción alguna para un paralelo en que, debiéndose graduar y comparar vicios con vicios, virtudes con virtudes y sucesos con sucesos, no cabe este cotejo entre personas cuyo carácter se presenta tan distinto y diverso. Lo que les causa más extrañeza es que precisamente haya contraído usted este empeño en una obra que dedica al bisnieto por línea paterna del mismo que oscurece y agravia en su paralelo, esto es, al rey nuestro señor cuya proximidad de sangre con Luis XIV es tanta como la del rey cristiano reinante, e igual (añaden) su interés en sostener el honor y estimación de un ascendiente cuya memoria no es sino muy gloriosa a toda su descendencia.

Así he oído discutir a varios franceses quejándose amargamente de usted en quien no esperaban que hiciese tanta impresión las especies malignas del rey, limerces, y otros calvinistas expulsos de Francia que ensangrentaron sus plumas contra Luis XIV en odio y venganza por la revocación del Edicto de Nantes ${ }^{8}$. Veremos como prorrumpe el sentimiento de la nación en París adonde me aseguran se ha remitido una traducción del paralelo hecha con todo cuidado. Entre tanto puede usted prepararse y si para ésto puede conducir el saber cómo piensan de este rey los que pasan por juiciosos en aquel reino, paso a manos de usted el adjunto Retrato político y moral que la casualidad ha traído a las mías.

8. El Edicto de Nantes se promulgó en 1598 logrando un período de paz y libertad religiosa para Francia. Pero el Rey Sol, deseoso de una unidad religiosa en su país, comenzó en 1661 una campaña de restricción de cuanto se autorizaba en el Edicto a los protestantes. En 1685 se consiguió revocar el Edicto obligando a miles de protestantes a salir de Francia. De esta forma Luis XIV cedió ante las presiones de los católicos que nunca habían renunciado a restablecer la antigua unidad religiosa del reino. Pero la expulsión de los protestantes supuso enormes pérdidas para la industria y el comercio que estaban en sus manos. 
Deseo los triunfos de usted en esta lid y cuantas le produzcan sus tareas literarias y sus órdenes en todas ocasiones para gustoso ejercicio de la singular devoción que le profeso y con que pido a Dios guarde a usted muchos años.

\section{RESPUESTA DEL PADRE FEIJOO A ORDEÑANA. OVIEDO 28 DE OCTUBRE DE 1750}

Muy señor mío: En la que acabo de recibir de usted del 12 del corriente veo un testimonio claro del afecto que le debo, siendo cierto que en el celo con que corrige mis yerros muestra el deseo que tiene de mis aciertos.

En el paralelo que en el tercer tomo de cartas hice del rey de Francia Luis XIV con el zar Pedro I de Moscovia halló usted una piedra de escándalo para la nación francesa que de resulta viene a serlo para usted. Por perecerle justa su queja de que yo haya rebajado, o pretendido rebajar, aquél gran rey de la estimación que por sus excelsas prendas ha merecido protesto a usted que siento mucho haber dado que sentir a la nación francesa porque la tributo, y he tributado siempre, especialísimo amor y respeto no habiendo en mí concepto alguno en él mucho más acreedora de uno y de otro. Mas por tanto deseara ver especificados los motivos de la queja no pudiendo, mientras ésos no se me descubran, asentir a que en el paralelo he ajado, como usted me dice, la memoria de Luis XIV.

¿No he confesado en él que este príncipe fue hombre discreto, de juicio sólido, de espíritu constante, bastantemente aplicado al gobierno, de una entrega regia mezclada con una afabilidad popular, amante de la justicia en cuanto no obstaba o a su ambición o a su deleite, estimador del mérito, humano, liberal, propenso a que en el reino florecieren las Artes, las Ciencias y el Comercio?. ¿No he confesado también inmediatamente que estas partidas son suficientes para constituir un buen rey y permitido (aunque afirmado) que sean bastantes para constituir un gran rey?. Hacia lo último del paralelo, ¿no expreso que no hallo repugnancia en conceder que fue un excelente rey, y que mereció el epíteto del grande?. Siendo todo esto así, no comprendo con qué justicia se me pueda acusar de que ultrajo su memoria.

Con todo, he representado al monarca francés no solo inferior pero muy inferior al rusiano es verdad; pero sin que esa inferioridad le quite ser un príncipe muy grande como a la Minerva de Fidias no quitó ser una estatua muy agigantada el ser de mucho menor bulto que el Coloso de Rodas. Para examinar en qué estatura deja mi paralelo al príncipe francés es menester medir la que yo concedo al rusiano. De éste asiento yo que en su reinado de veintinueve años hizo tantas cosas insignes que si las. viésemos ejecutadas en otro grande imperio por cinco o seis reyes en el espacio de siglo y medio, a todos esos cinco o seis aclamaríamos por unos príncipes de extremada habilidad, por consiguiente muy gloriosos y muy ilustres.

Ahora bien, supongamos que yo represento a Luis XIV de tal modo inferior al zar Pedro como si no hubiese ejecutado ni aún la mitad de las cosas insignes que hizo éste; pero como ésto no obsta a que hiciese tantas como dos de aquellos cinco o seis reyes imaginados o duplicados respecto de lo 
que hizo cualquiera de ellos, siempre le dejo lugar a que fuese un rey muy glorioso, pues sería rey glorioso cualquiera de los cinco, o seis, haciendo no más que la mitad que él hizo. Aún permitido que yo haya pintado al zar mucho mayor de lo que fue, nada obsta ésto a la justicia del paralelo porque en él no se compara la estatura de Luis XIV a la del zar según las dimensiones del original, en caso de ser éste menor que yo le he imaginado, sino según las de la imagen que yo formé aunque erradamente.

Pero no pienso yo haber errado el tamaño del zar Pedro porque le tomé fielmente la medida por sus muchas y grandes acciones; y éstas muchas y grandes acciones sobre haberse hecho notorias a toda la Europa se hallan testificadas por los mismos autores franceses. Bien lejos de haber añadido yo en el paralelo algo a lo que se halla escrito de él en el elogio histórico de este Príncipe compuesto por Mr. de Fontenelle estampado en la Historia de la Academia Real de las Ciencias del año de 1725 y en el Suplemento de Moreri del año de 1735, omití muchas circunstancias individuales que hicieron más completo su panegírico, y cómo se puede notar éste de apasionado cuando no he disimulado en él alguno los defectos de aquél monarca lo que pudiera hacer imitando el silencio de los autores del Suplemento de Moreri que acabo de citar, o la moderación con que mitiga Mr. Fontenelle el de la intemperancia callando enteramente el de la incontinencia.

Pero yo, por cumplir con la sinceridad que profeso manifesté sin disfraz alguno sus vicios imitando en ésto la de Juan Nestesuranoz y otros escritores moscovitas que los refieren. Nadie que haya leído la Historia de la Academia Real de las Ciencias compuesta por Mr. de Fontenelle pienso que me recusará. Este autor por el título de que escribió de el zar Pedro como panegirista, cumpliendo con la obligación que tenía aneja a su oficio de secretario de elogiar inmediatamente a su fallecimiento a todos los académicos de aquella sapientísima sociedad entre los cuales lo era honorario el gran Pedro nadie digo, de los que hayan leído aquella historia pienso que haga dicha recusación porque a cuantos lo han leído consta la exacta veracidad histórica que observó siempre este célebre autor en todos los elogios que compuso, como así mismo en todo lo demás que escribió perteneciente a la Historia de la Academia. Ni la cualidad de panegiristas es incompatible con la sinceridad de un escritor, si lo fuese, habríamos de notar de pocos sinceros algunos santos doctores que compusieron varios panegíricos.

A la autoridad de Mr. de Fontenelle añadiré la de otro autor francés de grande consideración en la materia presente, éste es Mr. Voltaire escritor de la Vida de Carlos Duodécimo Rey de Suecia. Digo que es de grande consideración en esta materia no sólo por su bella pluma y excelente crítica, sino porque habiendo constituido por su héroe aquel irreconciliable enemigo del zar Pedro no hay motivo para contemplarle apasionado por el monarca rusiano. Este autor pues, que reconoce a su héroe por uno de los mayores que tuvo el mundo, y bien claramente expresa que no lo hubo más o acaso ni igualmente esclarecido de veinte siglos a esta parte que es lo mismo que pasearse con Alejandro, sin embargo confiesa que ha tenido el todo de las prendas de uno y otro; el moscovita fue mayor hombre que el sueco lo que deja a aquél en una elevación incomparable. 
Al sueco apellidó, y aún apellida hoy toda Europa, el Alejandro del Norte porque la comparación del sueco y del macedón se halló naturalísima; al moscovita no se le aplicó por elogio el nombre de algún héroe de la antigüedad porque no se halló a quién compararle, o no se halló quién fuese comparable con él. Carlos de Suecia fue semejante a Alejandro de Macedonia, a Pedro de la Rusia nadie fue semejante y quien pretenda que éste es un mero hiperboleoratorio señálenos algún príncipe que haya hecho tantas y tan grandes cosas como él. Cuando el citado autor llega a referir la famosa batalla de Poltava, habla de los dos príncipes en términos que específicamente apoyan la preferencia que yo concedo al zar Pedro I sobre Luis XIV: El día 8 de julio, dice, del año 1709 se dio la batalla decisiva de Poltava entre los dos más célebres monarcas que había entonces en el mundo. Vivía entonces en el mundo Luis XIV, luego no era tan célebre como aquellos dos monarcas.

Instituye luego un paralelo entre los dos príncipes contendientes el cual concluye así: Carlos tenía el título de invencible de que en un momento podía ser despojado; las Naciones aíran y ha dado a Pedro Alejovitz el nombre de grande que una derrota no podía hacérsele perder porque no dependía de victorias ganadas. Sobre cuyas palabras hago dos reflexiones; la primera, que no la nación rusiana, o no sólo ella, sino las naciones en general, término indefinido, que comprende sin duda todas las europeas, dieron a Pedro el nombre de Grande. No fue a mi parecer tan general la conspiración de las naciones a dar el mismo título a Luis XIV. Y aún cuando llegaron a dársele vino a ser aquella voz no más que un eco de tantos gritos como primero habían dado los franceses tributando aquél renombre a su monarca. La segunda reflexión cae sobre el tiempo en que se dice que ya las naciones habían dado este título al zar Pedro, el año 9 de este siglo le halló ya exornado con el año de 96 del antecedente. Había empezado a reinar por sí solo, pues antes lo había tenido a todas las manos la igual autoridad de su hermano primogénito Juan.

Según esta cuenta mucho le sobró al zar Pedro para merecer al mundo el renombre de grande. Reinó desde el año de 96 del siglo pasado hasta el de 25 del presente; esto es, el espacio de 29 años. Antes de llegar a la mitad de esta carrera ésto es, en el año 13 de su reinado ya era llamado de las naciones Pedro el Grande. Todo lo que restó desde este año hasta el fin de su vida se empleó en una sucesión de acciones grandes, no sólo iguales, mas aún superiores a las de los primeros años. Todas éstas pues le sobraron para merecer el renombre de grande. De aquí resulta que aún concediendo como de justicia que Luis XIV es Ilamado Luis el Grande, sobran muchos materiales al mundo para erigir al zar Pedro una estatua colosal mucho más agigantada que la que merece Luis XIV. Y lo que es por mí, desde luego convengo en que el monarca francés se apellide Luis el Grande como el Rusiano se apellida Pedro el Máximo; a Pompeio no le defraudó el renombre de grande el que Cesar fuese mayor hombre que él, y el gran Pompeio se llamó y llamará aún después de que Cesar le venció.

Gayot de Pitaval en el tomo trece de sus Causas Célebres donde escribe la funesta historia de Alejo Petrowitz, hijo de Pedro I, después de copiar el citado paralelo de este monarca con Carlos rey de Suecia prosigue así: Ve aquí 
grandes cualidades en uno y otro acompañadas de algunos defectos. El lector determinará donde están los mayores defectos y las mayores virtudes, y lo que le obligará a conceder la ventaja al zar es que tenía más juicio que Carlos. Aquí hay dos cosas que considerar; la primera, que Gayot consintiendo, como en efecto consiente en el paralelo, virtualmente asiente al exceso que de él se infiere a favor del zar respecto de Luis XIV. La segunda, que afirmando que la balanza propende hacia la parte del zar por la ventaja del juicio, tácitamente confiesa que en las demás partidas quedan iguales. $Y$ no pudiendo negarse que dando la voz común de la Europa a Carlos el renombre de Alejandro del Norte, en esto mismo le reconoce por uno de los mayores héroes que tuvo el mundo; jen cuán incomparable altura queda colocado el que en todo lo demás es igual a tan gran héroe y superior en la soberana prenda del juicio!.

En esta gran elevación representan los hábiles autores que he citado al Gran Pedro y siendo tal su elevación, bien puede considerarse el rey Luis inferior a él y al mismo tiempo muy grande. La magnitud no se regla por una determinada medida lo propio digo del heroísmo. Un gigante sin dejar de ser gigante puede ser muy inferior a otro, ni quita a un héroe serlo que haya otro mayor. Yo he concebido tan eminente la estatua del zar Pedro, que debajo de él caven muchos príncipes ilustres aún con muy desigual graduación entre sí mismos, doy que le haya imaginado mucho mayor que realmente fue.

Este yerro en la medida en ninguna manera es injurioso a Luis XIV el cual puede ser tan grande cual le conciben los franceses más apasionados, y ser menor que la imagen de Pedro el grande que formé en mi idea aún concediendo que sea igual o superior a la verdadera dimensión del original. No pienso que haya franceses tan encaprichados de la gloria de su Luis XIV que piensen que arribó a aquél supremo grado del heroísmo en que nadie puede ser excedido. ¿Pero habré yo errado la medida que tomé a la estatura del zar?. Eso no es fácil se me haga creer sino me hacen creer primero que son falsos los grandes hechos suyos en que fundé el paralelo, y para falsificarlos es preciso no sólo desmentir a los historiadores moscovitas sino a algunos muy distinguidos escritores franceses como Mr. de Fontenelle, Mr. Voltaire, y los autores del Suplemento de Moreri citado fuera de que la pública fama abona aquellos hechos.

Háceme cargo usted de que yo para deprimir la gloria de Luis XIV atribuyo cuanto de grande se hizo en su reinado a los excelentes ministros que tuvo como si en ellos no tuviese parte alguna el monarca. Puede ser que alguna expresión mía diese motivo a usted para entenderlo así, pero ciertamente no fue ese mi pensamiento porque conozco muy bien que por buenos que sean los ministros poco podrán hacer destituidos enteramente del influjo del soberano. Estoy en que éste no sólo siempre hace algo, pero siempre hace mucho, aunque no se extienda a más que conocer la importancia de los buenos servicios, mostrarse reconocidos a ellos y dispuesto a premiarlos, coopera tanto a la continuación de ellos como los mismos que los ejecutaron. Una palabra obligatoria, un gesto apacible, un ademán gracioso, duplican y triplican el celo de un buen ministro incitándole a obrar según lo último de sus fuerzas aún a expensas o con dispendio de la propia vida. $Y$ no se puede negar que 
en esta parte importantísima del buen gobierno mostró una superior habilidad Luis XIV; nadie mejor que él conocía el mérito de los sujetos; nadie mejor que él sabía alentarlos a poner todos sus talentos en ejercicio, se hacía temer sin servirse de la amenaza, se hacía amar sin humillar la grandeza; nadie mejor que él acertó a componer la afabilidad con la majestad. No pocas veces su buen entendimiento ejercitado por su buen natural le sugería ya en palabras, ya en obras, unas expresiones de su estimación dotadas de una particular gracia con que obligaba infinito. Daré un ejemplo: cuando el famoso conde de Marsilli despojado con poca o ninguna razón por el emperador Leopoldo de todos sus honores militares fue a ofrecer su servicio a Luis $\mathrm{XIV}$, y como sujeto a un bien que voluntariamente a la ignominia padecida, apareció ante él sin el adorno de la espada, al momento que lo advirtió el monarca francés, con una dignación proporcionada a su noble ánimo, desciñiéndose el espadín que traía a la cinta se lo hizo ceñir al conde. Tiene esta acción en la línea de favor regio todo el brillante de cierta especie de heroísmo. ¿Qué incitativo tan valiente para emplear todas sus fuerzas en el servicio de Luis aquel gallardo boloñés!.

Así que los reyes de mil modos pueden influir, y de hecho influyen, en las operaciones de sus ministros siendo o tan imposible, o tan extraordinario, que éstos sin ese influjo hagan cosas de alta importancia que algunos historiadores tienen por fábula lo que refieren otros, de la letárgica inacción de los reyes de la primera estirpe francesa respecto de los triunfos de Carlos Martel y su hijo Pipino. Parten pues los ministros con los reyes la gloria de los hechos ilustres, y desde luego confieso que no es poca la que por esta parte le toca a Luis XIV pero reservando para el zar Pedro mucho mayor porción de ella, ya porque hizo mayores cosas en su reino que Luis XIV en el suyo, ya porque las hizo en mucho menor espacio de tiempo, ya en fin (y esto es lo principal) porque todo o casi todo lo hizo por si mismo, siendo él solo cabeza y mano, rey y ministro, director y ejecutor, agente e instrumento.

Si algunos escritores franceses no quisieren pasar por la desigualdad que constituyo entre los dos príncipes no me enzarzaré en que hagan las cuentas de otro modo y más a su gusto con tal que no pretendan que hago injuria a la memoria de Luis XIV, o bajo su grandeza sólo porque no convengo en que haya sido el más ilustre príncipe del mundo. Esto quiere decir que según la idea que tengo yo del zar, era menester que Luis XIV fuese superior a todos los demás príncipes que tuvo el mundo para ser igual a él. Quien considerase bien los hechos del zar hallará que en la línea en que él fue grande ningún monarca fue mayor porque nadie hizo más ni aún tanto como él hizo. ¡Con cuánta lentitud pasaron las ciencias y las artes de Egipto a Grecia, y de Grecia a Roma!. Pero el zar en un breve reinado introdujo todas las utilidades en una dilatadísima monarquía habitada por una gente ignorantísima que resistía con indecible obstinación su propia enseñanza. ¡Qué valor, qué constancia, qué magnanimidad, qué capacidad, qué fatiga, qué aplicación era menester para esto! mayormente cuando sino todo, la mayor parte, lo hizo por sí solo.

Pero en obsequio a Luis XIV y de sus más ardientes apasionados no disimularé una respuesta que se me puede dar a ésto y a cuanto escribí en el 
paralelo, y es que el que Luis XIV no haya hecho tantas y tan grandes cosas como el zar en ningún modo prueba que no fuese dotado de iguales y acaso superiores talentos y virtudes a las del monarca rusiano, porque aquella desigualdad en los hechos pudo depender precisamente de no hallarse materia a qué aplicarlos. Explícome.

Luis XIV entró en la corona de Francia hallando ya introducidas las artes y las ciencias en aquel reino con que no pudo ya introducirlas sino perfeccionarlas y en esta parte no se puede negar que hizo mucho. Acaso si hallase a la gente francesa tan bárbara como el zar halló la rusiana haría otro tanto como éste hizo; y acaso si el zar hallase en su reino las ciencias y las artes en el estado en que las halló Luis XIV en el suyo no haría más que lo que Luis XIV hizo. Valga lo que valiere esta solución no replicaré contra ella ni haré el más leve esfuerzo para privar a los de Luis XIV de la complacencia que puede ocasionarles tan agradable imaginación. Sólo diré que la proposición de que Luis XIV puesto en las circunstancias del zar haría otro tanto como él hizo no tiene más verdad que la correlativa que acaso no lo haría.

No pienso que sea menester más que lo dicho para no caer en la aprehensión de que mi paralelo haya ocasionado la menor displicencia a los dos monarcas bisnietos de Luis XIV, son entrambas muy razonables para ofenderse de lo que nada tiene de ofensivo. Supongo que conocen y aprecian las grandes prendas de su ilustre bisabuelo; yo también las conozco y las publi$\mathrm{co}$, pero como no tengo por gusto el concepto de que en grandeza de acciones el zar Pedro no le igualase y aún excediese, les haría yo injuria en atribuirles un dictamen que no juzgo acertado sobre lo cual no tengo que hacer más que remitirme al paralelo. Pero renovando la protesta hecha de que estoy pronto a corregirle si por la parte opuesta se me dieren noticias más constantes que las en que yo fundé el paralelo.

Al cargo que me hace usted (cualificándole cargo de conciencia) de haber dicho que Luis XIV fue incontinente casi de por vida cuando hechos los cálculos legítimamente me sacan al menos las dos terceras partes de ella exentas de este vicio, lo cual usted explica señalando por principio de su relajación en esta parte la comunicación con La Valliére y por término en matrimonio con la Maintenon. Convengo en la explicación y lo que resulta es que aquél gran rey fue incontinente desde la edad de veinte años hasta la de cincuenta y dos, pues de la historia consta que a los veintidós empezó la comunicación con La Valliére; y de lo que usted sienta que el matrimonio con la Maitenon duró veinticinco años se deduce que contrajo con ella a los cincuenta y dos pues murió aquel monarca a los sesenta y siete. Ahora señor, cuando escribí que la incontinencia en Luis XIV fue un vicio casi de por vida, es evidente que en la voz vida no fue mi intento significar todo lo que en rigor filosófico se llama vida, sino sólo aquel espacio de ella en que regularmente hay vigor para ejercer la incontinencia, por cuya regla se debe descartar del significado de mi cláusula una gran porción de las dos extremidades de la vida, esto es, la infancia, la puericia y la edad sexagenaria. De este modo mi expresión sólo comprende cuarenta y cuatro años de la vida de Luis XIV; esto es, desde la edad de diez y seis hasta la de sesenta de cuyo número treinta años contados desde los veintidós hasta los cincuentidós hacen más que las 
dos terceras partes. Conque a mi parecer no se necesita demasiada benignidad para interpretar mi cláusula de modo que se me de un sentido verdadero y sea lo que fuere de la inteligencia que otros quieren darla, yo protesto que en este sentido la proferí no siendo entonces ni ahora mi ánimo suponer manchada del vicio de la incontinencia la vida de Luis XIV sino los treinta años expresados; bien que no faltan quienes, retardando más su matrimonio con la Maintenon, alargan a mayor espacio de tiempo su comercio con la Montespan.

Por no fatigar la atención de usted con una carta muy larga reservo para otra una parte, y acaso la más importante, de lo que tenía estimado para ésta asegurando entre tanto a usted, que no siendo inferior mi docilidad a mi sinceridad, si como sincero en el paralelo de los dos monarcas escribí lo que realmente sentía. Como dócil estoy pronto a corregirle en todo aquello en que me presenten noticias opuestas y más seguras que aquellas que dieron fundamento a mi escrito.

\section{RESPUESTA ORDEÑANA-FEIJOO. MADRID, 12 DE DICIEMBRE DE 1750}

Muy señor mío: Sorprendiéndome gustosamente el día 29 del pasado con la estimable carta de usted del 28 de octubre que ya no esperaba, haciéndome temer su atraso que no hubiese llegado a manos de usted la mía del 12 de septiembre a que responde en ella este imaginado extravío.

Me era sensible porque no tenía seguridad de que por otro conducto se hallase usted con noticia de la impresión que hizo en los franceses el paralelo entre Luis XIV, rey de Francia, y Pedro I, zar de Moscovia, de que me pareció informar a usted sólo para su precaución sin otro objeto. Usted no lo ha entendido así cuando dice que yo hallé en él una piedra de escándalo para la nación de Francia que de resulta venía a serlo para mí. Este es un supuesto ajeno de la letra y espíritu de mi carta en que a poco que reflexione usted hallará que observo la más exacta neutralidad, suspendiendo mi juicio sobre el paralelo y refiriendo sin parcialidad lo que aquí oí a varios franceses.

Creo muy bien que no quiso usted darles que sentir en él bastándome que lo diga usted para que no dude de ello. Convengo también en que no fue su intento ajar la memoria de Luis XIV. No obstante expresa usted que las buenas cualidades que indica de este príncipe son insuficientes para constituir un gran rey mucho más para adaptarle por renombre el epíteto de Grande; que no halla usted ni inacción heroica en toda su historia; que en las circunstancias que estaba la Francia cuando entró a reinar haría lo mismo que él otro cualquiera rey que aplicase a ello; que la única gloria que sólidamente le queda es haber conocido (como si para esto bastase un entendimiento común) los grandes talentos de algunos vasallos suyos, haberlos empleado y atendido y que aún en esta parte, cayó en gravísimas faltas pues por unos celos o recelos propios de un corazón pusilánime (¿hay más que decir?) retiró al duque de Orleans y al príncipe de Conti del manejo de las armas. ¡Oh! y lo que penetró en el gabinete de Luis XIV el que ha suministrado a usted estas noticias. 
Aún quiero creer que no fue el ánimo de usted quitarle el epíteto de Grande con hacer mayor y aún máximo al zar pues no es incompatible lo uno con lo otro y no ignoro que el comparativo dice el positivo en el sujeto comparado. Lo que yo celebrara es que lo entendiesen así cuantos han visto y vieren el paralelo, pero lo tengo por difícil o imposible porque no les constan como a mí las intenciones de usted y los coloridos con que usted pinta en él a Luis XIV ni con señas de mediano le dejan.

Lo que más me admira es que para probar la superioridad del zar se auxilie usted con el Elogio Histórico de Fontenelle, La vida de Carlos XII de Suecia ${ }^{9}$ escrita por Voltaire y el Suplemento del Diccionario Histórico de Moreri ${ }^{10}$. Ninguno mejor que usted puede conocer lo despreciable de estas autoridades y su incongruencia para que puedan entrar en el asunto presente. Ya se sabe que en las oraciones laudatorias, cuales un elogio histórico, sólo se apuntan las acciones que pueden dar lustre al sujeto elogiado glosándolas ventajosamente a fin de que parezcan más agigantadas de lo que son. Los vicios se callan, y si se toca alguno, es con la mitigación que usted mismo observa en el de Fontenelle sin que por esto se pueda concluir que falta a la verdad.

En el Suplemento de Moreri hallará usted que es mayor todavía el cuidado de no decir cosa que pueda ofender a las personas que nombra, a lo menos directamente, en sus respectivos artículos. Fuera de que su crítica es ninguna y la escasa noticia que da de cada una deja poco campo para la graduación y justa estimación de ellas.

Por lo que mira a Voltaire no descubro en qué pueda fundar usted el concepto tan alto que forma de él, sus escritos no corren en la República Literaria ni con mediana reputación y últimamente ha decaído tanto la de este autor en Francia que ya no se hace caso de él, motivo sin duda que le ha precisado a buscar su fortuna fuera de aquel reino habiéndose transferido a Berlín en donde al presente se halla. Pero vemos que sea su autoridad del peso que usted supone, ¿qué ilación sólida puede hacerse a favor de la superioridad del zar sobre Luis XIV de una expresión suya, si no hiperbólica muy casual, cual es haberse dado la batalla de Poltava entre los dos más celebres monarcas que eníonces había en el mundo?. Aún tomada en el sentido de usted no es aplicable la comparación a Luis XIV a quien su avanzada edad ponía fuera de tal cotejo y de la clase de contemporáneo de los dos príncipes competidores con que no sale la consecuencia de que fue menos célebre que ellos, ni el mismo Voltaire la concedería si se le consultase. Mas si usted tiene a Voltaire por autor de tanta excepción en la materia presente a causa de su excelente críti-

9. Esta obra la tiene Ordeñana en italiano. En las cartas no se hace mención a la obra que sobre Luis XIV escribió Voltaire en 1751 y que fue editada por primera vez en Berlín, Le siècle de Louis XIV. No obstante, Ordeñana la tuvo en su biblioteca antes de 1754.

10. Este Diccionaire Historique lo encargó Ordeñana en Amsterdam en 1750. Así aparece en una relación de pedidos que hizo a dicha ciudad y que se encuentran en el AGS. Secretaria de Guerra, Suplementos, leg. 174. En lengua castellana no apareció este libro hasta 1753 y fue editado en París para luego venderse en España. En 1762 el gobierno prohibió la venta de este libro en defensa de la producción nacional. 
ca, ¿̇porqué toma usted de él lo favorable y calla lo adverso?. En su citada Historia de Carlos XII no reconoce este escritor prenda alguna de héroe en el zar diciendo que obraba menos como tal que como príncipe, siempre por interés y nunca por generosidad, ¿dónde está pues aquel gran heroísmo con que usted le preconiza incomparable: similis illi non fuit ante eum Rex?. El propio Voltaire dice en ella que una sola de las grandes cualidades de Carlos era capaz de hacer inmortal a cualquiera otro príncipe de que se desentiende usted; sin embargo, ¿de qué vale tanto este elogio como el que da usted al rusiano diciendo que sus acciones insignes distribuidas en cinco o seis reyes serían capaces de hacerlos gloriosos a todos?

Otra ilación aún menos concluyente a mi entender; saca usted las palabras que cita de Gayot de Pitaval" y expresa usted que copiando este autor el paralelo entre el zar Pedro y el rey Carlos de Suecia y dejando al lector que determine en cual de los dos hay mayores vicios y virtudes, dice que lo que le obligará a conceder la ventaja al primero es que tenía más juicio que el segundo. Guiado de esta autoridad discurre usted así a Carlos dándole la voz común de Europa el renombre de Alejandro del Norte y le reconoce por uno de los mayores héroes que tuvo el mundo. Es así que el zar fue mayor que él en el juicio, luego el zar es incomparablemente mayor que Luis XIV. Esta es la consecuencia que saca usted pero que no hallo yo salga de las premisas como lo juzgará usted mismo si reflexiona sobre ella y no desprecia los preceptos de la forma silogística.

Pretende usted que no puede notarse de apasionado su paralelo pues no disimila en él alguno de los defectos de el zar bien que pudiera hacerlo imitando el silencio de los autores del Suplemento de Moreri. No discurro a qué pueda venir esto, ni qué conexión tenga con un paralelo un Diccionario Histórico en que sin cotejo alguno sólo se tocan en extracto o resumen tales cuales circunstancias de los sujetos. No es presumible sin agraviar a usted que lo traiga para hacer ver que pudiera, disimulando los defectos del zar, referir los de Luis XIV y pues así, mérito de haber manifestado lo primero sin disfraz, creeré sea porque los considera más graves que los segundos en lo cual alguna ventaja, y no de poca consideración, deja usted traslucir a favor del monarca francés si no es que excluya las virtudes morales de toda proporción a constituir la grandeza de un príncipe.

Sin más autoridad que la de Voltaire supone usted que las naciones europeas dieron al zar el renombre de Grande con que ya se halló exonerado el año de 1709, y de aquí infiere usted que habiéndose empleado desde entonces todo el resto de su vida en una sucesión continuada de acciones grandes no sólo iguales sino superiores a las de los primeros años, le sobraron todas éstas para merecer aquel título haciéndole acreedor aun al de Máximo comparado con el de Luis XIV. Este argumento o nada prueba o si prueba algo, es a favor del monarca francés a quien sin cumplir todavía la mitad de la carrera de su reinado reconocían y apellidaban Grande, no sólo los gritos de los

11. Gayot de Pitaval, Causes célebres et interesantes, dieciocho volúmenes. Años 1738 y siguientes. Ordeñana los tuvo todos en su biblioteca. 
franceses como usted dice y las naciones de Europa, sino también las de todo el mundo habiéndose extendido tanto los ecos de su grandeza que en obsequio de ella los príncipes más remotos de la Asia le embijaron embajadores que la hallaron aún mayor que la fama.

Después de aquella época continuó Luis XIV haciendo cosas muy grandes con que según el modo de inferir de usted, podremos decir que igualmente que al zar le corresponde el epíteto de Máximo. Haciendo usted como que pone en tortura o prensa su entendimiento para exprimir algo que sea favorable a Luis XIV, indica la supuesta que se le puede dar de que el no haber hecho este príncipe cosas tantas y tan grandes como el zar no prueba que no tuviera superiores talentos y virtudes pues pudo depender de la variedad de circunstancias, y dejando usted como por medio sin réplica esta solución dice al fin que la proposición de que el monarca francés puesto en las circunstancias del rusiano haría tanto como él, no tiene más verdad que la correlativa que acaso no lo haría. Con esto reduce usted a juguete la intención de su hipótesis y piensa hacer gracia en no declararla por imposible. Pero no está tan desnudo de mérito Luis XIV que necesite recurrir a posibilidades aún en competencia con el zar. Veamos si me engaño, usted lo decidirá.

Empiezo por la religión que es y debe ser en orden, dignidad y aún atribución la primera de las virtudes que constituyen el verdadero heroísmo. Sienta usted que la herejía estaba en Francia enteramente abatida y sin fuerzas cuando se revocó el Edicto de Nantes, lo que es incierto era entonces respetable. El partido de los hugonotes no sólo por su número sino también por su opulencia y por el lustre y autoridad de nuevas personas que aún seguían esa secta. Más de trescientas familias salieron del reino con sus bienes que al principio se les permitió extraer y después no a vista del daño inmenso que resultaba a la Francia; por no perderlos aparentaron muchos que abrazaban la religión católica, otros muchos se convirtieron a ella sinceramente habiéndoles tocado Dios el corazón y no pocos en el Languedoc, Bretaña, Bajo Delfinado y otras partes se mantuvieron en su error pero sin ejercicio público como aún hoy subsisten no habiéndose tenido por conveniente empujarlos a salir por no acabar de arruinar las provincias con su total despoblación. Fueron entre los expulsos muchos artífices del reino que quedó muy perjudicado con la traslación de sus mejores fábricas a Inglaterra, Holanda, Hamburgo, Dinamarca y varios parajes del Norte. Todos estos inconvenientes y otros que se previeron hubo que superar para la revocación del Edicto la que muchos de los mismos católicos le reprobaban y aún hoy no faltan quienes la lloren. Vea usted pues si no hubo más que quererla y decretarla y si para disponer la materia tendría que hacer Luis XIV en los años precedentes de su reinado.

No paró en esto su celo por la religión. Sólo tuvo como se sabe la Bulla Unigenitus ${ }^{12}$ y contuvo el jansenismo que iba haciendo rápidos progresos en toda la Francia. Dispuso y costeó repetidas expediciones de misioneros apostólicos para predicar y establecer el evangelio en Africa, Asia y América y

12. La Bulla Unigenitus promulgada por Clemente XI en 1712 supuso la condena de la iglesia al jansenismo. 
¿qué no hizo y no intentó para restablecer al rey jacobo en el trono de Inglaerra de que le arrojaron sus súbditos en adoro de la religión católica?. No lo debe ignorar usted si ha leído las memorias de aquel tiempo escritas por autores fidedignos ni dejar de confesar la superioridad incomparable de Luis XIV en esta parte sobre el zar Pedro que no profesó religión alguna habiendo sido a lo más un mero deísta.

Fue Luis XIV amantísimo de la Justicia que hizo respetar más que ninguno de sus predecesores habiendo corregido la relajación que habían causado en ella las guerras civiles y promulgado para su más recta y pronta administración los mejores reglamentos y ordenanzas que aún hoy se conocen en toda la Europa y que usted puede ver en el que llaman los franceses Código ó Code Louis. Me es muy reparable que habiendo tanto que decir y aplaudir en esto no hable usted sino de la prohibición de duelos y que no haga memoria de otras admirables providencias y establecimientos de buen gobierno que honran la de aquel príncipe y en que le fue deudor el zar por lo que aprovechó con tales documentos sin tener que hacer más que mandarlos seguir y practicar en sus dominios.

En la parte militar, bien examinado el todo de ella, se hallará que si no más no fue menos glorioso Luis XIV que el zar. Porque si se mira a las tropas no son las que mantuvo este príncipe en su mejor estado comparables con las de aquél en fuerza, disciplina y bizarría; si a las plazas de guerra, basta decir que sólo el Mariscal de Vauban ${ }^{13}$ fortificó más de trescientas muchas de planta desde sus primeros fundamentos; si a conquistas, véanse los tratados de pares y se comprobará que son más los que el monarca francés cedió en varias ocasiones que las que consiguió el rusiano en toda su vida éste, hasta la batalla de Poltava no hizo más que huir de Carlos XII y aunque le fue muy útil no le dio extraordinario honor aquella difícil victoria ganada sobre un ejército que no componía la cuarta parte del suyo, fatigado, desnudo, falto de víveres y de municiones, cortado, sin artillería, y con su rey herido y fuera de estado de acudir a donde era necesario su presencia. En la guerra que después siguió contra la Suecia que se hallaba atada por tres o cuatro potencias al mismo tiempo, sin fondos, sin tropas, sin generales, y sin su soberano, poco tuvo que hacer el moscovita para adelantar sus conquistas pues no había quien se las disputase, lo que no sucedió en las de Luis XIV.

A ésto veo me ocurre usted en carta y paralelo diciendo que este príncipe debió las suyas a sus generales, no así el zar que todo lo hizo por sí mismo a lo que respondo por partes. Más de veintidós sitios mandó en persona Luis XIV sin otras operaciones militares en que dio repetidas pruebas de su gran corazón y bizarría y de aquel heroico valor que ha sido siempre característico de la Augusta Casa de Borbón. No pretendo que en esta parte superase al zar pero sí que no lo cediere en ella como tampoco en el talento de dirigir una acción de guerra estando a favor del primero que no se le vio lograr alguna por mala conducta; y contra el segundo, que la empeñó fuera de toda regla

13. Comisario Real de Fortificaciones en el reinado de Luis XIV. 
militar a las márgenes del Pruth ${ }^{14}$ donde cometió errores crasos, dejando pasar el río a los turcos sin oposición y no habiéndoles atacado cuando entraban en su campo sin dar lugar a que formasen y le encerrasen. Esta es no obstante, una de las dos ocasiones que usted cita para elevar el heroísmo del zar, que nunca le acredito menos, y si no véanse en el mismo Voltaire los extremos a que lo redujo encerrado en su tienda, la agitación de su ánimo consternado; compárele usted en este lance con Carlos XII en Poltava y dígame a qué lado cae la balanza del heroísmo y si este título es aplicable al zar.

Ya se sabe el estado infeliz y decadente en que estaba la Marina de Francia cuando entró a reinar Luis XIV y su casi total aniquilación con las Guerras Civiles que perturbaron la menor edad de este príncipe. Así que salió de tanta confusión y formó el plano que había de seguir en el gobierno de sus dominios; pensó no sólo en restablecer la Armada Naval, sino también en llevarla a la fuerza y esplendor a que nunca había llegado. Con este invento hizo construir navíos, puertos y arsenales que no habían establecido las Compañías de Guardias Marinas para criar buenos oficiales, formó las clases y listas de gente de mar tan útiles para cualquier pronto armamento, ejercitó la marinería para habilitarla y al fin, con estos únicos medios, logró poner su marina en estado de poder competir con las de Inglaterra y Holanda unidas y conseguir sobre ellas repetidas victorias haciendo respetar el pabellón de la Francia que antes estuvo en sumo abatimiento; la del zar nunca llegó a este grado de elevación y gloria.

La ciudad de Petersburgo edificada, poblada, fortificada y adornada por este monarca no hay duda que le da mucho honor pero aún junto con lo restante de sus obras, que merecen alguna atención, no equivale con mucho a lo que hizo Luis XIV en esta línea. En prueba de ello pararé la consideración con la multitud de villas, plazas y fortalezas que hay con su nombre no sólo en Francia sino también en sus dominios ultramarinos que todas le han debido el ser habiendo en la América poblaciones de éstas que pueden competir con las mejores de Europa; pues qué diremos de los suntuosos palacios y famosos jardines de Versalles, Atarli, Tullerías y otros, qué de la célebre Máquina de Atarli, qué de la Gran Casa de Inválidos de París, monumento el más insigne de su grandeza y piedad y qué finalmente (si puede haber final en esto) del portentoso Canal de Languedoc que une y comunica los dos mares obra que sola llena la idea de gran poder, espíritu incomparable y magnificencia sin igual de Luis XIV.

Dice usted que este príncipe cuando entró a reinar halló ya establecidas en Francia las Ciencias y las Artes y que así no tuvo que introducirlas sino perfeccionarlas; perdone usted le diga que parece equivocarse en esto. Es verdad que el Cardenal de Richelieu fundó la Academia de las Ciencias pero la dejó tan en embrión y tan poco asegurada que ni memoria hubiera quedado de su existencia si no la hubiera, digámoslo así, animado Luis XIV dotándola liberalmente y mejorando su instituto con nuevos reglamentos de forma que si no el título de fundador de esta Academia se le puede dar el de

14. La batalla de Pruth tuvo lugar en 1711 entre Rusia y el Imperio Otomano. 
restaurador, conservador y protector de ella. Las que no halló establecidas y tuvo que erigirlas y ponerlas en el estado actual de perfección son la Real de Inscripciones y Buenas Letras, la de Arquitectura, la de Pintura y Escultura en París y Roma sin otras muchas de éstas y otras facultades que fundó en todo el reino. Estableció también las fábricas de lana, lienzo, sedas y otras manufacturas que subsisten hoy $y$ de que han resultado los grandes progresos del comercio interior y exterior de la Francia. Otros establecimientos utilísimos hizo aquel monarca para promover las Ciencias y las Artes y asegurar la mejor educación de la juventud en que pudo aprender el zar y copió sin duda, si no el todo, gran parte de lo que practicó en sus dominios.

No por eso dejo yo de reconocer el gran mérito del zar y de confesar que hizo algunas cosas singulares pero tendré siempre por más gloriosos sus deseos que sus medios y muchos de éstos por más afortunados que bien dirigidos a juicio de hombres prudentes. No pasarán por heroicas muchas de sus extravagancias en que tuvo más parte el capricho que la discreción; para ser gran constructor, excelente hombre de mar y perfecto general de tierra (partes que jamás se han visto juntas en un hombre) no necesitaba ser carpintero, grumete, y tambor. Hubiera valido más que el tiempo que inútilmente empleó en ésto lo hubiera dedicado a otras preferibles importancias del gobierno. Para instruir en tan ínfimos ejercicios a sus vasallos bastábanle los operarios y prácticos que trajo de fuera, si lo hizo por inspirar en ellos la subordinación no era menester tanto en unos hombres casi esclavos que no conocían más principio de obrar que la voluntad absoluta y despótica de su soberano. Por esta razón y otras no hallo en qué pudiesen consistir los grandes embarazos que dice usted se oponían a los designios de este príncipe.

Aquella gente aunque sin cultivo, ruda y tosca, era como una materia informe susceptible de cualquiera forma que se la quisiere infundir. Un tronco mientras se mantiene tal está dispuesto a que se le de ésta o la otra configuración pero si llega a tener una queda inhábil para las demás que antes podía recibir. Así sucede con los pueblos mal habituados en quienes no basta (y ojalá no lo experimentemos) el empeño más eficaz ni la autoridad más firme para que dejen el vicio contraído que ya la costumbre les constituye naturaleza, en tal estado debe considerarse la Francia antes que cesaran las guerras civiles. Estaba invertido en aquel reino todo el orden del gobierno, los parlamentos querían dar luz al soberano, la nobleza no se creía en obligación de obedecer y aspiraba al mando, el pueblo hacía burla de la justicia, la religión estaba despreciada, sin premio y abatida la virtud y dominante el vicio y todo finalmente en una confusión y desorden que hacía difícil el remedio. Dígame ahora que en tales circunstancias hubiera hecho cualquiera lo que Luis XIV.

Usted juzgará con su conocida probidad si es o no digno de alguna consideración lo que llevo expuesto a favor de este monarca, y si basta o es insuficiente para que usted forme de él mejor opinión que la que descubre en su paralelo. A mí no me mueve espíritu alguno de parcialidad, no pretendo que a Luis XIV se tenga por más de lo que fue ni al zar por menos de lo que usted le representa si lo mereciere. En que cada uno de estos príncipes guarde su debido lugar en el concepto de las gente. Me interesa la Justicia y la Verdad 
que son mis mayores amigas como no dudo lo sean de usted y pues conozco y confieso la superioridad de sus luces, me sujetaré gustoso a su decisión y agradeceré la instrucción que me ofrece usted y espero en la segunda parte de su respuesta. En tanto remito a usted las seguridades de mi fiel devoción a su persona deseando me mande y que legue Dios.

\section{RESPUESTA DE FEIJOO A ORDEÑANA. OVIEDO, 23 DE NOVIEMBRE DE $1750^{15}$}

Muy señor mío: Cumplo lo que ofrecí a usted en la carta antecedente continuando en ésta el asunto de aquélla en la cual reconozco que quedé algo diminuto cuanto a la parte de satisfacer a usted sobre el cargo de que mi paralelo podría ocasionar displicencia a los dos monarcas por lo que quiero suplir ahora lo que faltó entonces.

Suponía yo, y aún debía suponer, que los dos monarcas no tendrían formado un concepto más alto de las glorias y virtudes de su ilustre bisabuelo que el que tenía formado yo; digo que debía suponerlo por cuanto con un juicio reflejo asentía a que mi concepto era enteramente conforme a los méritos del objeto y así atribuir a los dos monarcas un concepto discrepante del mío, sería atribuirles un concepto cerrado.

Pero los que me culpan el paralelo no se satisfacen con esto porque no atienden al concepto justo que pueden hacer los dos monarcas arreglado a los méritos del objeto, sino a un concepto apasionado que pretenden ellos les haya influido la comunicación de la sangre; y esto sí que realmente es ofenderlos. Yo les atribuyo un juicio recto dictado por la razón porque tal juzgo el que expuse en el paralelo. Mis censores sin examinar si es recto o no lo es o prescindiendo de uno y otro suponen en ellos aquel dictamen que juzgan les inspiró la pasión. ¿Quién en esta parte es injurioso a los dos monarcas mis censores o yo?

Añado que aun cuando supongan mis censores el influjo de la pasión del parentesco, porque los dos monarcas prefieren en el conjunto de virtudes su ilustre bisabuelo al emperador de la Rusia, deben hacer cuenta de un insigne contrapeso que dentro de ellos mismos tiene esa pasión. ¿Cuál es éste?: su amable, dulce y pacífica índole. Explicáreme.

Es cierto que aunque fueron dos muy grandes príncipes Luis XIV y Pedro I no lo fueron por el mismo camino, ni este renombre dio el mundo a los dos por la misma especie de méritos, o por lo menos la especie de mérito que principalísimamente se lo adquirió, fue muy diversa. A Luis XIV le adjudicaron principalísimamente el renombre de Grande las muchas victorias que logró sobre sus enemigos; a Pedro I los muchos insignes beneficios que, a costa de inmensas fatigas, hizo a sus vasallos. Creo pues firmemente que el genio de los dos monarcas que hoy rigen a España y Francia benéfico y apacible como lo tienen ambos, más los conduce a hacerse gloriosos por el rum-

15. Esta es la carta que aparece transcrita en SÁNCHEZ AGESTA, L., Escritos... pp. 535-542. 
bo que hizo glorioso a Pedro Y que por aquél que granjeó a Luis XIV el epíteto de Grande.

$Y$ especialmente si fijamos los ojos en nuestro monarca Fernando el Justo, ¿qué cuidados vemos en él, sino los mismos que el monarca rusiano?. Conducir artífices, maestros, instrumentos, no sólo para el uso, más también para la enseñanza de ciencias y artes útiles, promover el comercio activo, colocar sobre un buen pie la Marina, construir arsenales, fortificar puertos; en fin, procurar con varias providencias la seguridad y comodidad de sus vasallos sabiendo que ésto es lo que constituye un rey grande, glorioso, excelente y no llover fuego sobre sus vecinos, derribar muros, inundar de sangre las campañas.

Mas descubriendo a usted enteramente mi corazón le añado ahora que aunque al formar el paralelo no pensé escribir cosa que fuese del desagrado de los dos monarcas, tampoco tuve la mira de adularles o complacerles sí sólo la de exponer lo que me dictaba la razón y la conciencia. Más digo: aun cuando supiese que uno y otro daban en su mente la preferencia a su ilustre bisabuelo sobre el Emperador rusiano, si me considerase capaz de hacerles mudar de dictamen lo pretendería sin duda porque eso se me representaría ser lo más conveniente a sus augustas personas y mucho más a las innumerables de sus vasallos. Voy a dar la razón.

La manía en que dio el mundo de celebrar como dignos de una fama inmortal a todos los grandes conquistadores fue varias veces perniciosa a muchos reinos por lo que influyó en no pocos príncipes el deseo ardiente de hacerse famosos por este camino. Las lágrimas que derramó Julio Cesar leyendo la Historia de Alejandro por la triste reflexión de que no había hecho aún cosa muy memorable hallándose en una edad en que aquel conquistador había sujetado muchos reinos, mostraron la grande ansia que tenía de imitarle y el deseo de imitarle fue fatal para los romanos y a una gran parte de Europa y de Asia. El propio efecto hizo en nuestros días la lectura de la misma historia en Carlos XII de Suecia siendo aún niño y aunque se le representó para templar su anhelo a seguir los pasos de aquel héroe que Alejandro murió antes de cumplir la edad de treinta y tres, intrépido respondió: bastante vive quien muere después de haber conquistado reinos. ¿Y qué produjo esta emulación con Alejandro?. Algunas ilustres victorias a la verdad pero esas victorias le costaron la casi total ruina de su propio reino de Suecia.

De modo que el haber ligado el mundo por un error insigne la idea de herósmo a la ambición desmesurada de conquistadores atrevidos y felices ocasionó éstos y otros muchos estragos que se leen en las historias, porque siendo algunos príncipes de capacidad y valor que el común de los hombres celebrará como héroes dignos de suprema admiración aquellos ilustres guerreros que hicieron eterna su fama con sus conquistas, se encendieron en ardiente apetito de buscar su gloria por la misma senda, y buscando la gloria por esa senda, ejercieron una horrenda carnicería sobre gran porción del género humano en que fueron también comprendidos sus propios vasallos.

¿Ve aquí usted por qué en el paralelo di la preferencia al zar Pedro sobre Luis XIV?. Nunca serán objeto de mis elogios los príncipes apellidados grandes sólo por sus conquistas porque esto es un pésimo ejemplo para sus sucesores. Si pudiese yo a cuantos mandan el mundo diría lo primero que el 
patriarca de los conquistadores fue Nemrod, que eso significa lo que dice la escritura ipse cepit esse potens in terra, y el supremo ejemplar de los príncipes pacíficos, Cristo, Señor nuestro, que por eso le llama Isaías Principes pacis. Les diría lo segundo, que lo que constituye los ilustres reyes y dignos de la imitación de la posteridad no es supeditar a sus vecinos, sino hacer felices a sus vasallos. Les diría lo tercero, que es mucho más difícil y pide mayor capacidad lo segundo que lo primero porque lo primero, de parte del conocimiento, no pide más que pericia militar; lo segundo, necesita de una extensión de luces dilatadísima siendo cierto que compensándose la felicidad de un reino de una gran multitud de providencias pertenecientes a diversísimas especies, además de la necesidad de penetrar con claridad cada una, es imposible abarcarlas todas y hacer las inexcusables combinaciones de todas ellas sin una comprensión casi sobrenatural. Les diría lo cuarto que no sólo pide ésto mucha capacidad, mas también mucho valor y una constancia tal vez más que heroica porque a cada paso ocurren obstáculos que vencer y contradicciones que desarmar como sucedió al zar Pedro.

Y cuánta firmeza de ánimo es menester para no desmayar cuando algunas de las providencias tomadas, o por ciertos accidentes adversos, o por la menor pericia de los ejecutores (lo que es muy común a los principios) salieron inútiles. Les diría lo quinto, que mirado por la parte de la moralidad es infinito el exceso que hace un rey que sólo atiende al bien de sus vasallos y aquel que aplica su ánimo a conquistar. Lo primero es virtud, lo segundo es vicio y con esto se dice todo. Aquél obedece a Dios, éste a su ambición o a su codicia.

No por eso pretendo que esta contraposición sea con la mayor propiedad adaptable a los monarcas que fueron objeto del paralelo porque el rusiano también fue conquistador y el francés no sólo triunfó de sus enemigos, pero también hizo cosas muy buenas en beneficio de sus vasallos, sí sólo que el primero no sólo por sus conquistas logró el epíteto de Grande, sino por insigne bienhechor de sus reinos de lo cual es prueba clara lo que dice Monsieur de Voltaire que antes de la batalla de Poltava ya habían conspirado las naciones a decorarle con ese epíteto, y antes de la batalla de Poltava no había hecho conquista alguna, o sólo muy leve, que no podía compensar la gran derrota que padeció delante de Nerva. Al contrario Luis XIV, principalísimamente se lo adjudicaron la fortuna y el acierto de sus militares expediciones aunque no dejó de merecer aplausos por sus ideas hoy providencias domésticas.

Acaso habrá alguna falencia èn tales cuales noticias de aquellas que me sirvieron al paralelo, de las cuales, por tanto, no me constituyo fiador; antes oiré con docilidad a cualquiera que más bien fundado me las corrija. No sólo con docilidad, mas también con gusto y complacencia, porque pudiendo hacerlo sin dispendio de la verdad, mucho más inclinado me siento a preconizar las glorias de un príncipe, sobre católico y vecino, ascendente de un monarca a quien adoro, y de otro, a quien venero, que las de otro heterodoxo, distante $y$ que por ninguna parte puede inspirarme algún afecto apasionado.

Supongo que en caso que a los ojos, o a los oídos de los dos monarcas reinantes llegase mi dictamen en esta materia, no hallándole conforme al suyo, le hallarían no con indignación, sino con desprecio; sin embrago de lo cual, 
estoy siempre constante en que en la suposición moralmente imposible de que postrado ante su trono se dignasen oír mis voces, nunca les propondría como modelo proporcionado a su imitación a algún príncipe guerrero, o famoso por sus expediciones militares, sino a aquellos que incesantemente se aplicaron a procurar el mayor bien para sus reinos: justos, pacífico, padres de sus vasallos, representándoles esta gloria como de mucha mayor solidez y realidad que aquélla; pero dejando lugar a las guerras que persuadiese un derecho constante o la necesidad de una justa defensa. Quiero al príncipe pacífico, mas no cobarde; moderado, mas no insensible; religioso, mas no encogido; $y$ en fin, que los confirmantes le vean apacible pero armado; con la espada envainada, pero ceñida.

$\mathrm{Ni}$ yo he pensado jamás de calificar de injustas todas las guerras que movió Luis XIV. En la que emprendió para reponer en el trono de Inglaterra al desposeído Jacobo II, obró como príncipe católico y como generoso y honrado vecino; $y$ en la que sostuvo para mantener en la corona de España a su nieto, nuestro Felipe $V$, hizo lo que pedía la justicia. Para otras fue opinión común de la Europa, y aún pienso que lo sea hoy, que más fue estimulado de su genio guerrero y ambicioso de gloria que de la razón dejando aparte si tuvo la idea de la monarquía universal que algunos le atribuyeron pero nunca lo juzgué verosímil, aunque leí lo que relativamente a este asunto escribió nuestro famoso español Don Manuel de Lira en el libro que intituló Idea y proceder de la Francia cuando este libro era de la moda.

\section{RESPUESTA ORDEÑANA-FEIJOO. MADRID, 31 DE DICIEMBRE DE 1750}

Muy señor mío: He recibido la carta de usted del 23 del pasado que contiene la segunda parte de su respuesta a la que le escribí sobre el paralelo y veo que en ella se explica usted en términos aun más indulgentes que en la primera hacia Luis XIV rey de Francia declarándole, no solamente grande, sino muy grande, que vale lo mismo que máximo.

A este reconocimiento sí que suscribirán gustosos los que llama usted censores del paralelo si con tal voz se han de entender los franceses de que hablé en mi citada carta, pues por él vienen a quedar plenamente desagraviados habiéndose quejado únicamente del vilipendio con que se trata en aquél escrito a su monarca sin meterse en comparaciones odiosas. Mas no por ésto espere usted que se adhieran al juicio del paralelo ni que haya quien crea que injuria a los dos actuales reyes de España y Francia considerándolos de contrario dictamen a los de usted, pues siendo el suyo ajustado a la razón hacer mérito con ambos soberanos, no sólo en esto, sino también en indicar la reputación injustamente ultrajada de su esclarecido bisabuelo. En ésto no se mezcla vicio alguno de pasión sino es que lo sea el reconocimiento del mérito de nuestros mayores que se nos propone para el ejemplo o que haya ley que obligue a declararse contra ellos, idea tan absurda no cabe en el buen juicio de usted; ni la de que el contrapeso que pone a la pasión del parentesco en la amable, dulce, y pacífica índole de los mismos dos príncipes, los constituya en la obligación de negar a Luis XIV la justicia que no le niegan sus propios enemigos. 
Por más que quiera usted mitigar el paralelo con explicaciones favorables a este monarca no lograría que deje de pasar por injurioso a su memoria ni que le miren con ceño los que, aún desnudos de toda parcialidad, sólo se interesan en que quede ilesa la verdad. Es tanta la decisión y claridad con que usted corre la pluma en él que no deja lugar a interpretación alguna; ni puede usted sostenerle sin ponerse en contradicción consigo mismo si ha de ser por el medio que lo intenta en sus cartas pues en éstas confiesa usted que fue grande Luis XIV y en el paralelo pone su empeño en todo lo contrario. No hay responder a esto; que no fue grande por la misma especie de mérito que lo fue el zar pues sea lo que fuere de esta diferencia (de que hablare abajo) lo cierto es que en el paralelo no sólo en contraposición del moscovita, sino fuera de este cotejo, dice usted positivamente que nada hizo el monarca francés que le diese derecho al renombre de grande, y en comprobación de ello sino bastasen los pasajes citados en otra carta precedente, traería otros del mismo paralelo no menos claros y expresivos.

No halla mi cortedad en qué pueda fundarse la ocurrencia o conjetura que hace usted de que a Luis XIV le adjudicaron principalmente el epíteto de Grande sus victorias y al zar los beneficios que hizo a sus vasallos; yo diría (y es más verosímil) que uno y otro debieron este honor al conjunto de sus plausibles acciones. Como quiera, no descubro la proporción que usted figura en el segundo para que se prefiera al primero en la representación de objeto digno de la imitación de los dos reinantes. Si excluye usted a Luis XIV por conquistador debe también excluir al zar que lo fue con una ambición desbordada; y si antepone a éste por insigne bienhechor de sus pueblos lo fue asimismo logrando en sus tiempos felices que hasta el horror de la guerra se convirtiese en utilidad y delicia de sus súbditos.

Nuestro monarca Fernando y su primo dos veces hermano Luis XV tienen ejemplos ilustres que seguir sin salirse de su familia en las dos líneas de España y Francia. No necesitan buscarles atenta distancia como la Rusia ni de un príncipe extraño cuyo carácter personal no forma modelo digno y cuyo estudio y mérito se redujo a imitar él mismo y practicar en sus dominios lo que vio establecido en otros. Más tuviera que decir en el asunto pero lo dejo para no molestar a usted. Mas no habiendo sido otro mi ánimo en esta carta que indicar algo que le de ocasión de hacer muchas reflexiones para reformar el juicio del paralelo si hallase que no es el que debe ser usted es dócil y amante de la verdad como dice, y lo creo, y no dudo se ponga de parte de ella a cualquier lado que la encuentre sin que le desvíe ni embarace el afecto con que naturalmente se miran las producciones propias. Yo seguiré siempre mi propensión a estimar y servir a usted cuya vida guarde Dios.

\section{RESPUESTA FEIJOO-ORDEÑANA. 26 DE ENERO DE 1751}

Muy señor mío: Recibí de usted de 31 de diciembre en la cual me lleva especialmente la atención una cláusula en la que me dice que: si excluyo del objeto digno de la imitación de los dos reinantes a Luis XIV por conquistador, debo también excluir al zar que lo fue con una ambición desbordada; $y$ si antepongo a éste por insigne bienhechor de sus pueblos, lo fue así mismo 
aquél logrando en sus tiempos felices que hasta el horror de la guerra se convirtiese en utilidad y delicia de sus vasallos.

En lo primero convengo de bonísima gana pues bien lejos de proponer al zar digno de imitación por sus conquistas positivas, expresamente culpo en ellas su ambición y mala fe como usted puede ver en el numero cinco del paralelo. Fuera de no hallar cosa expectable en ellas porque me combatió con fuerzas muy superiores. Mas en cuanto a lo segundo, que aún el horror de la guerra que mantuvo Luis XIV se convirtiese en utilidad y delicia de sus vasallos me es preciso disentir sobre un fundamento cuya solidez no me puede negar usted. En el pasado mes de septiembre me hizo usted el favor de remitirme un papel hermosamente escrito en idioma francés a quien legítimamente en la carta adjunta dio usted el nombre de Retrato político y moral de Luis XIV añadiendo en ella que lo que toque a Luis XIV dicho papel es lo que piensan de este rey los que pasan por juiciosos en aquel reino, esto es el de Francia.

Ahora pues, en la octava plana de este escrito veo que su autor después de hablar en general de las victorias de Luis XIV en aquellos tiempos en que sus armas fueron felices prosigue así: si la gloria de la Francia por esta parte ejerció hacia fuera en ninguna manera fue por eso feliz hacia dentro. Las artes, antes florecientes, decayeron; las manufacturas y el comercio dieron consigo en tierra; la campaña se despobló; el reino fue entregado a la avaricia de los arrendadores, plaga más terrible que todas las de Egipto; éstas fueron las utilidades que Luis XIV produjo a Francia con sus victorias.

Yo sospecho que o usted no leyó el papel citado sí que hizo concepto de él por ajeno informe o lo leyó algo distraído; a no ser así no me hubiera escrito que yo usé de noticias que leí en La Rey, Limusus y otros herejes. Pues cuanto escribí de los vicios de Luis XIV se halla por muy extenso en dicho papel en prueba de lo cual yo me ofrezco a firmarle de mi nombre, sin otra limitación que la de excluir al zar, de la proposición que Luis XIV fue el mayor príncipe de su tiempo.

Consiguientemente, el concepto que yo hice de Luis XIV es el mismo que hacen los que pasan por juiciosos en aquel reino. Así mismo, cuanto el autor de este escrito dice de sus prendas y virtudes lo asenté yo en el número veinte del paralelo, con que lo que únicamente puede quedar por mi cuenta es haber dicho que el zar fue mayor que él. Pero si yo representé a Luis XIV en su debida estatura sin rebajar sus virtudes ni exagerar sus vicios, el que yo escribiese mayor al zar, aunque en ello errase, será un defecto de mi crítica sin ser injuria al monarca francés. Mas en esto de crítica cada uno tiene la que Dios le dio, y nadie me quitará a mí que admire más al zar labrando con la hacha en la mano piezas de navio en Holanda por espacio de dos años, que Alejandro con la espada en la diestra ganando en la Asia victorias sobre victorias.

Esta y las demás diligencias así durísimas y extraordinarias que el zar hizo para erigir de bestias a racionales los habitantes de un dilatadísimo imperio, extremamente tenaces de su antigua barbarie, me representan en un heroísmo mucho más sublime y noble que los de Alejandro, Cesar, Ciro, Sesortris y otros destrozadores del linaje humano. 
Yo no pienso en importunar con más réplicas a usted a quien estimo infinito, que haya juzgado mi paralelo no indigno de su crítica rindiéndole al mismo tiempo muy cordiales agradecimientos de que en el Retrato político y moral de Luis XIV me ha presentado usted un completísimo defensorio para cuantos ataques se puedan hacer a mi paralelo. Dejándome únicamente expuesto a los que puede padecer mi persona de parte de aquellos que me notan de imprudente en haberle dado a la luz pública en que yo dejaré que cada uno sienta lo que quisiere porque tengan siquiera ese consuelo mis enemigos. Nuestro Señor guarde a usted muchos años.

\section{RESPUESTA ORDEÑANA-FEIJOO. MADRID, 28 DE FEBRERO DE 1751}

Muy señor mío: Es tal el concepto que me merece la veracidad y superiores talentos de usted que en su carta del 26 del pasado casi me persuado a que había errado la inteligencia del papel francés que le remití con la mía del 12 de septiembre. Pero reconocí lo contrario habiéndolo leído nuevamente y dádole e leer pues no sólo no hay ni encuentran en él la conformidad que supone usted en el paralelo sino que es muy diversa la idea que da de Luis XIV. Vamos al cotejo.

¿Qué dice el paralelo?. Dice (perdone usted esta repetición pues lo que no se tiene a la vista se olvida fácilmente) que las buenas partidas que confiesa usted en este príncipe no son suficientes para constituir un gran rey y permitido que lo sean, no bastan para constituir un rey tal que merezca adaptársele por renombre el epíteto de grande; que en ninguna manera arribó a la grandeza del heroísmo pues no ejecutó ni halla usted en toda su historia, acción alguna de héroe; que las cosas buenas que hizo no pedían o extraordinarios esfuerzos o alcances superiores; que en las circunstancias en las que entonces estaba la Francia otro cualquier rey que se aplicase a ello haría lo mismo; que todo lo que se adelantó en el comercio, en la marina, en edificios públicos, en Ciencias y Artes se debió a sus ministros y las ventajas que logró en las guerras con sus vecinos a los excelentes generales que tubo sin que se pueda decir (añade usted) que él los formase, o en alguna manera concurriese a hacerlos tales.

Dice también que bien considerado todo la única gloria que sólidamente queda a Luis XIV de las grandes cosas que se hicieron en su reinado es haber conocido los grandes talentos de algunos vasallos suyos, haberlos empleado y atendido, que aún dentro de esta especie cayó en algunas gravísimas faltas pues por unos celos o recelos propios de un corazón pusilánime retiró al duque de Orleans y al príncipe de Conti del manejo de las armas, que le adularon mucho sus vasallos y aun no pocos forasteros, y no faltó sino consagrar sus propios vicios dándoles el nombre de virtudes lo que en parte tampoco faltó. Pero que nota usted en algunos escritores franceses que tomaron la pluma posteriormente a su fallecimiento una tal languidez en sus elogios que teme usted que pasado un siglo ya el eco de los panegíricos que se le hicieron durante su vida no suene, o el humo de los incendios que se le tributaron se disipe y que aún concediendo usted que mereció el epíteto de Grande duda que en la conservación de este epíteto hacia la posteridad logre la dicha 
de su antecesor el glorioso Carlo Magno en quien la expresión de la grandeza se unió con tanta estrechez al hombre que vino a hacerse parte del nombre la expresión de la grandeza.

¿Qué dice el papel con que me reconviene usted?. Dice que la Francia ha visto pocos reyes tan gloriosos como Luis XIV y que tal vez no ha tenido alguno que haya juntado en su persona cualidades más singulares ni que haya sostenido más dignamente el renombre de Grande en todos los tiempos de su vida; que su entendimiento era grande, juicioso, sólido, elevado, y que sabía escoger los medios más propios para la ejecución; que era secreto y constante en sus empresas, bizarro, habiéndosele visto entrar muchas veces a la parte de la fatigas y los peligros con sus tropas, magnífico, dando todo en él más alta idea de grandeza, verdaderamente cristiano y religioso, devoto en la oración, modesto en los templos, sumiso a los decretos de la Iglesia, celoso contra los errores y las novedades en materia de fe, buen padre, buen amo y buen rey.

Dice también que sus virtudes civiles, militares, políticas y cristianas hicieron en el espacio de cincuenta años la materia más ordinaria de sus elogios; que fue paciente y resignado en las adversidades sin que éstas le abatiesen aquella heroica firmeza que sólo se halla en los hombres singulares; grande siempre pero aún mayor en la muerte que fue de un verdadero héroe y perfecto cristiano; que a pesar de la magnitud y de la calumnia vivirá su nombre en los fastos de la Francia y la posteridad le colocará con los de Carlo Magno y Clodis. Que digan lo que quisieren los enemigos de la gloria, muchos reyes han tenido sus defectos pero pocos sus virtudes que ésta es una justicia que han hecho todas las naciones y le ha negado solo la exegia entera. Diga usted ahora que este papel es un completísimo defensorio para cuantos ataques se pueden hacer a su paralelo que sospecha usted que no le leí o le leí distraído, y por conclusión que le firmará usted de su mano. No dudo lo hará usted por ceder a la verdad y a la razón que hallan fácil acogida en un entendimiento claro y en un genio dócil como el de usted, pero en este caso será preciso renunciar la defensa del paralelo en que todo el empeño de usted es deprimir el mérito de Luis XIV para dar más cuerpo al zar Pedro con tanta parcialidad que usted mismo le llama más panegírico que paralelo.

El argumento que cree usted ad hominen y con que empieza su carta tiene a mi ver fácil solución. La proposición que en él impugna usted consiste en dos partes; la una, es que Luis XIV fue bienhechor insigne de sus pueblos; la otra, que en sus tiempos félices hasta el horror de la guerra se convirtió en utilidad y delicia de sus vasallos. La primera parte no necesita de prueba porque lo es la opulencia presente de la Francia que se debe a aquellos fundamentos, ni hubiera podido esta potencia subir al alto grado en que la puso aquel príncipe haciendo infelices a sus vasallos.

Paso a la segunda parte que es la que ataca usted expresamente; la extensión de los límites, el aumento de las rentas, el engrandecimiento del poder y el crédito ganado en la Europa son ventajas reales que produjeron a la Francia las Guerras de Luis XIV en sus tiempos felices, por medio de ellas su comercio reclusó antes en el continente del reino por el predominio marítimos de los ingleses se amplió a las cuatro partes del mundo y sus progresos 
dieron fomento a las manufacturas multiplicándose éstas a proporción de la mayor salida que tenían sus géneros. Con esto se adelantó la industria sin que faltase gente para ella, para el estudio de las Artes y las Ciencias y para el cultivo de los campos. Los ejércitos sólo se llevaban la superflua de que abundaba y abunda la Francia aun para inundar otros reinos, y ya se sabe que siendo prósperos los sucesos no es tanta la que se pierde porque es menos la deserción y la mortandad en prueba de que con la guerra no padeció la población. No hay sino leer los padrones o registros de aquel reino y se hallará que era mayor al fin del siglo pasado que a la mitad de él, no obstante el gran número de familias que echó fuera la revocación del Edicto de Nantes.

Es conocida la propensión de los franceses a interesarse en las disputas de religión, las que ocasionó el jansenismo envolvieron a muchos y el empeño hubiera tenido fatales consecuencias contra la quietud pública a no haberse distraído la atención de aquellos naturales con las guerras que sobrevinieron. Tuvieron también éstas la favorable resulta de evacuar y limpiar la Francia de toda la gente ociosa y vagante que como humor pecante podía viciar su constitución.

Aún más logró Luis XIV y fue que sus ejércitos no le fuesen tan gravosos y costosos como lo eran a otros príncipes los que le oponían. Pues con las contribuciones que sacaba del país enemigo se ayudaba a sostener los gastos de campaña y la mayor parte del producto de ellas entraba en el reino en cambio de lo que éste suministraba para la subsistencia de la tropa. Enriqueciéronse en la guerra muchas familias, otras se ennoblecieron y no hubo quien no tomase parte en la gloria de las armas y en las satisfacciones de su monarca que era generalmente amado. Con ésto y ser continuas las celebridades de batallas ganadas, plazas tomadas y otras prosperidades estaba como embelesada la nación; miraba con placer la causa de ella y se iba connaturalizando con la guerra. Tales fueron los efectos de ésta cuando era feliz, no así cuando dejó de serlo que fue al principio de este siglo.

De ofensiva que había sido antes se convirtió en defensiva, se cambió enteramente la suerte y el aspecto de ella. Ya no se oían sino lástimas, los enemigos iban penetrando en la Francia de cuyas provincias fronteras exigían gruesas contribuciones, todo el peso de la guerra cargaba sobre los interiores que ya no podían con tanto, de éstas habían de salir los fondos para mantener los ejércitos y la gente para restablecer y emplear los cuerpos con que era consiguiente que se empobreciesen y despoblasen y que trascendiese el daño a las fábricas del reino para la interrupción del comercio. Puede ser que ocupado el autor del citado papel de estas fatalidades de la última guerra aplicase inadvertidamente lo que usted copia de él a las precedentes, sin reflexionar que no era adaptable a ellas pues ni produjeron la decadencia que se supone de las artes, ni dieron en tierra con las manufacturas y el comercio, aun cuando éste padeciese una pequeña suspensión, ni despoblaron la Campiña hasta el punto de quedar incultos los campos por falta de labradores.

Todo ésto y cuanto en este particular llevo dicho lo sé de personas fidedignas que alcanzaron aquellos tiempos y de lo que he visto en mis verídicas negociaciones de cortes y otros documentos que comprueban la común opinión de que las guerras que eran ruinosas a otros estados eran útiles a la Fran- 
cia y que por eso las emprendía fácilmente y las seguía con tesón Luis XIV. Sino conviene usted en que el autor del papel padeciese equivocación en el tiempo a que refiere el pasaje mencionado desisto y cedo gustoso separándome de esta parte del sentir del mismo autor de quien diré lo que a otro intentó San Pablo: in hoc non laudo. Pero aun así, no hallo que usted mejore su causa pues en el paralelo se oscurece de intento la grandeza de Luis XIV y en el otro escrito se conoce y declara ésta no como quiera, sino en grado heroico, dándose a sus virtudes el valor y mérito correspondiente que es como piensan de este príncipe los que pasan por juiciosos en Francia. $Y$ tanto basta para salvar mi proposición.

Soy con usted en que demos punto a nuestras conferencias sobre el paralelo porque no habiendo servido las razones con que le he impugnado sino de empeñar más a usted en su defensa sin duda para la ineficacia o ningún convencimiento de ellas. Preveo fundadamente que sucederá lo mismo con las que nuevamente le exponga en posición de las suyas que siempre responderán a la acreditada capacidad de usted sin el menor resabio de preocupación sin amor propio. Dios guarde a usted muchos años como deseo. 